\title{
NEWS
}

\section{Intercropping enables a sustainable intensification of agriculture}

\author{
Wopke VAN DER WERF $(\bowtie)^{1}$, Chunjie LI ${ }^{1,2,3}$, Wen-Feng CONG ${ }^{2}$, Fusuo ZHANG $(\bowtie)^{2}$ \\ 1 Plant Sciences, Crop Systems Analysis Group, Wageningen University and Research, 6708PB Wageningen, the Netherlands \\ 2 College of Resources and Environmental Sciences, National Academy of Agriculture Green Development, \\ China Agricultural University, Beijing 100193, China \\ 3 Soil Biology Group, Wageningen University and Research, 6700AA Wageningen, the Netherlands
}

Intercropping is the cultivation of more than one crop species on a single parcel of land. Intercropping seeks to exploit species complementarities to capture more of the available light, water and nutrient resources, and thus increase combined crop yield ${ }^{[1]}$. Intercropping is well known in China, where smallholder farmers practice a great diversity of species combinations to increase their yields ${ }^{[2]}$. Figure 1 illustrates intercropping as done by a farmer in Gansu Province, China, who chose to combine wheat, soybean and maize. This three-way combination offers several species complementarities. First, the growing period of wheat ends earlier than that of soybean and maize, so the soybean and maize can use all the light, water and nutrient resources of the land after wheat harvest. With the wheat covering only around half of the area, the plants will still produce about $70 \%$ of the normal yield for wheat grown as a sole crop, because the wheat has virtually no competition for resources early on, resulting in greater capture of light, water and nutrient resources in the intercrop than in a sole $\mathrm{crop}^{[3]}$. Furthermore, soybean and maize have a complementarity for nitrogen acquisition, with maize requiring nitrogen from soil, but soybean being able to fix it from the air. Therefore, this combination can reduce fertilizer requirements ${ }^{[4]}$.

In a new paper in Nature Plants ${ }^{[5]}$, Li et al. report that intercropping grain yields are on average $1.5 \mathrm{t} \cdot \mathrm{ha}^{-1}$ greater than would be expected from the sole crop yields and the relative proportions of species in the mixture. When only Chinese intercropping is considered, the grain yield gain is even larger: $2.1 \mathrm{t} \cdot \mathrm{ha}^{-1[6]}$. The land equivalent ratio of intercropping was previously found to be around $1.22-1.30^{[4,7,8]}$. This means that growing crops in mixtures improves land use efficiency and also reduces the resource inputs associated with cultivating these crops. Xu et al. ${ }^{[4]}$ showed that intercropping reduces fertilizer requirements while Mao et al. ${ }^{[9]}$ and Tan et al. ${ }^{[10]}$ provide evidence that intercropping saves water. By concentrating production of grain on less land, and exploiting mechanisms of complementarity for resource capture between species, intercropping thus can make land available for other uses, and it can also reduce resource inputs, such as nitrogen fertilizer and water, that need to be used more sparingly in agriculture to reduce the environmental burden of overuse. Li et al. ${ }^{[5]}$ found that the greatest yield advantages were associated with intercropping with maize using a partial overlap in growing period between species, with species grown in strips with adequate amounts of fertilizer. Smaller yield advantages were associated with intercrops in which the species had the same growing period, and in which legumes were combined with small grain cereals, such as wheat or barley, in full mixtures to obtain sustainable yields with reduced nutrient inputs. This alternative approach to production is also prevalent in places outside China, e.g., in Europe ${ }^{[11]}$. Both the high- and low-input approach to intercrop production resulted in a substantial reduction in the land and fertilizer requirements of production compared to sole crops at the same level of input.

Overall, the new study highlights the potential of intercropping to increase yield, reduce inputs, and achieve overall more sustainable production with a greater capture of resources for producing yields. Intercropping can therefore

Received June 2, 2020

Correspondences: wopke.vanderwerf@wur.nl, zhangfs@cau.edu.cn

(C) The Author(s) 2020. Published by Higher Education Press. This is an open access article under the CC BY license (http://creativecommons.org/licenses/by/4.0) 


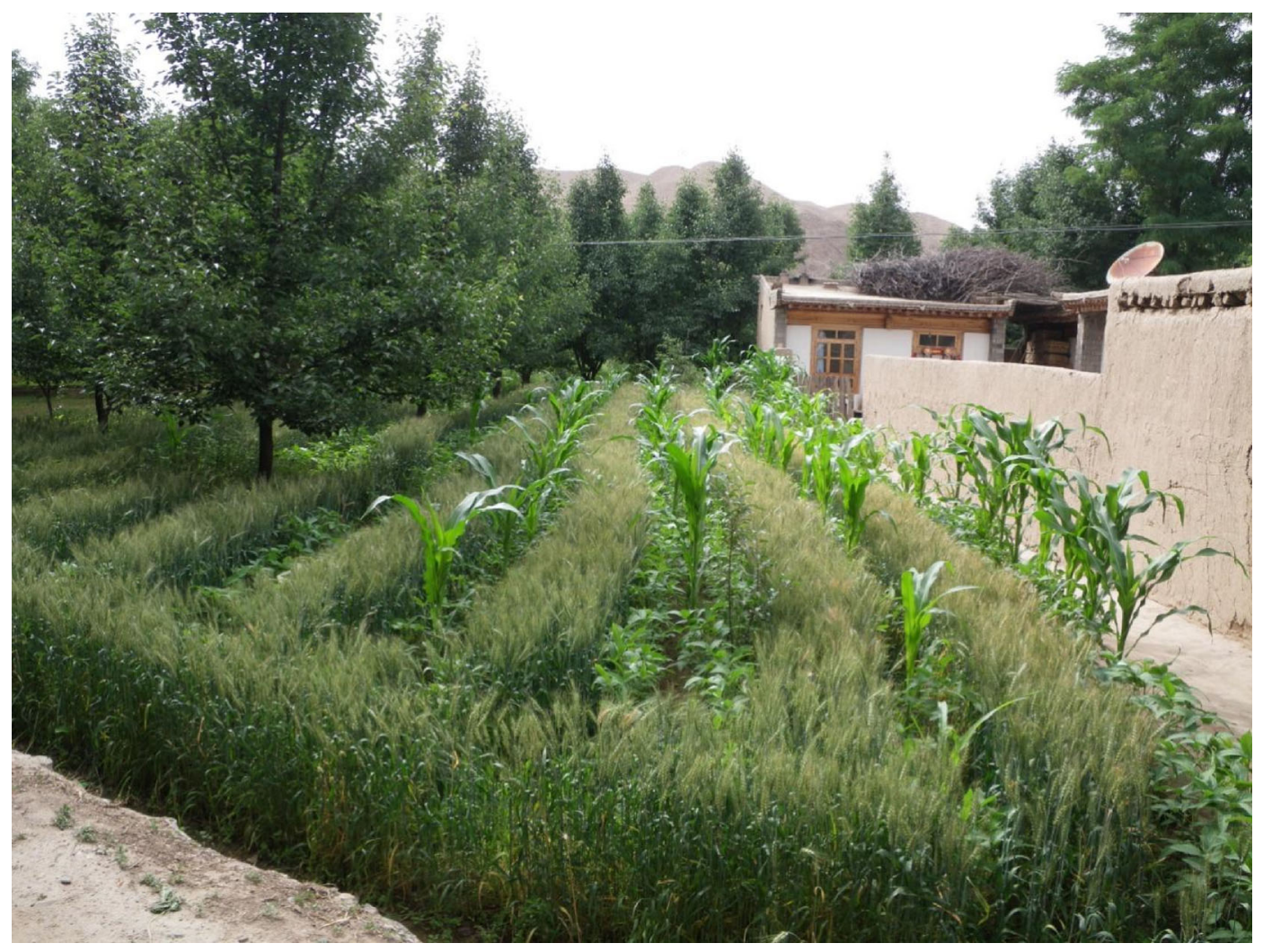

Fig. 1 Intercropping of wheat, soybean and maize in a smallholder field in Yingping Village along the Yellow River in Gansu Province, China (original photo by Wopke van der Werf).

enable the intensification of agriculture within a reasonable footprint ${ }^{[12,13]}$. Challenges remain to mechanize intercropping and engage farmers and enterprises manufacturing machinery that may be used in intercropping. With global changes necessitating sustainable intensification to maintain yields but reduce the environmental footprint of agriculture, intercropping offers an opportunity that humanity cannot afford to ignore.

\section{References}

1. Stomph T J, Dordas C, Baranger A, de Rijk J, Dong B, Evers J, Gu C, Li L, Simon J, Jensen E S, Wang Q, Wang Y, Wang Z, Xu H, Zhang C, Zhang L, Zhang W P, Bedoussac L, van der Werf W. Designing intercrops for high yield, yield stability and efficient use of resources: are there principles? Advances in Agronomy, 2020, 160: 1-50

2. Li L, Zhang L, Zhang F. Crop mixtures and the mechanisms of overyielding. Levin S A, ed. Encyclopedia of Biodiversity, (2nd ed.), 2013, 382395

3. Zhang L, van der Werf W, Zhang S P, Li B G, Spiertz J H J. Growth, yield and quality of wheat and cotton in relay strip intercropping systems. Field Crops Research, 2007, 103(3): 178-188

4. Xu Z, Li C, Zhang C, Yu Y, van der Werf W, Zhang F. Intercropping maize and soybean increases efficiency of land and fertilizer nitrogen use: a meta-analysis. Field Crops Research, 2020, 246: 107661

5. Li C, Hoffland E, Kuyper T W, Yu Y, Zhang C, Li H, Zhang F, van der Werf W. Syndromes of production in intercropping impact yield gains. Nature Plants, 2020, 6(6): 653-660

6. Li C, Hoffland E, Kuyper T W, Yu Y, Li H, Zhang C, Zhang F, van der Werf W. Yield gain, complementarity and competitive dominance in intercropping in China: a meta-analysis of drivers of yield gain using additive partitioning. European Journal of Agronomy, 2020, 113: 125987

7. Yu Y, Stomph T J, Makowski D, van der Werf W. Temporal niche differentiation increases the land equivalent ratio of annual intercrops: a metaanalysis. Field Crops Research, 2015, 184: 133-144

8. Martin-Guay M O, Paquette A, Dupras J, Rivest D. The new Green Revolution: sustainable intensification of agriculture by intercropping. Science of the Total Environment, 2018, 615: 767-772

9. Mao L, Zhang L, Li W, van der Werf W, Sun J, Spiertz H, Li L. Yield advantage and water saving in maize/pea intercrop. Field Crops Research, 2012, 138: 11-20 
10. Tan M, Guo F, Tjeerd J S, Wang J, Yin W, Zhang L, Chai Q, van der Werf W. Dynamic process-based modelling of crop growth and competitive water extraction in relay strip intercropping: model development and application to wheat-maize intercropping. Field Crops Research, 2020, 246: 107613

11. Bedoussac L, Journet E P, Hauggaard Nielsen H, Naudin C, Corre Hellou G, Prieur L, Jensen E S, Justes E. Eco-functional intensification by cereal-grain legume intercropping in organic farming systems for increased yields, reduced weeds and improved grain protein concentration. Organic Farming, Prototype for Sustainable Agricultures, 2014, 47-63

12. Du J, Han T, Gai J, Yong T, Sun X, Wang X, Yang F, Liu J, Shu K, Liu W, Yang W. Maize-soybean strip intercropping: achieved a balance between high productivity and sustainability. Journal of Integrative Agriculture, 2018, 17(4): 747-754

13. Tilman D. Benefits of intensive agricultural intercropping. Nature Plants, 2020, 6(6): 604-605 